\title{
The Effectiveness of Authentic Assessment with Early Childhood E-Port Information Systems at PAUD
}

\author{
Leni Gonadi \\ Early Childhood Education \\ Unviersitas Negeri Malang \\ Malang, Indonesia \\ leni.gonadi.fip@um.ac.id
}

\begin{abstract}
This study aims to describe the use of early childhood e-ports and determine the effectiveness of authentic assessments with early childhood e-port assessment information systems. Based on the use of early childhood eport information systems in PAUD institutions in Malang City. The approach in this study is a quantitative ex-post facto approach. The results of the research data show that the implementation of authentic assessments using the e-port information system of early childhood is concluded to be well received. It was concluded that the use of early childhood eport information systems was effective in improving the implementation of authentic assessments in PAUD institutions throughout the city of Malang with a presentation rate of $76.5 \%$, where the higher use of e-port in early childhood, the implementation of authentic assessment would be more effective. Low use of e-port early childhood, the implementation of authentic assessment will be increasingly less effective.
\end{abstract}

Keywords-e-Port, early childhood, authentic assessment

\section{INTRODUCTION}

Application of early childhood education curriculum in 2013 through Permendikbud No. 137 of 2014 concerning National Standards for Early Childhood Education and Permendikbud Number 146 of 2014 concerning 2013 PAUD Curriculum has been implemented evenly in the city of Malang. In accordance with the implementation of the 2013 Curriculum in the implementation of Early Childhood Education today, a competency-based curriculum, a continuous learning approach from process assessment and results is applied that provides an overview of the level of achievement of child development embodied in attitudes, knowledge and skills competencies.

Assessment of processes and outcomes in early childhood education refers to authentic assessment. Authentic assessment in 2013 Curriculum is "assessment of process and learning outcomes to measure the level of attainment of attitude competencies (spiritual and social), knowledge and skills carried out continuously" [1]. The assessment does not only measure what is known by children but rather emphasizes measuring what can be done by children.

The application of authentic judgments is inseparable from the problems that arise, especially in the implementation of assessments that refer to the authentic K13 PAUD assessment. Based on the results of observations and interviews with the heads of PAUD and PAUD educators in the city of Malang found the following things; 1) authentic assessment carried out focused on assessing the results of children's activities, 2) assessment rubrics found similar for all developmental achievements, 3) institutions using excel applications to assess the existence of an average score that is not in accordance with the principle of authentic assessment in early childhood. This is similar to what was conveyed by the Head of the Office of Education and Culture of Malang City, Zubaidah, emphasizing that so far no school has provided a report to him regarding the difficulties faced in implementing K-13. The only thing considered to be a difficulty is the scoring system [2].

Malang City Education Agency through the Field of Guidance for Educators and Education Personnel of Malang City in collaboration with the PG PAUD S1 study program through community service programs held a training on the use of early childhood e-port assessment information systems for PAUD educators to overcome the difficulties of implementing authentic assessments carried out on September 2017 with 30 PAUD educators from 30 PAUD institutions in Malang. Based on the results of these activities there are 15 PAUD institutions that have used early childhood e-port information systems in the implementation of authentic assessments.

Based on this background, the researchers wish to examine the "Effectiveness of Authentic Assessment in PAUD Institutions with Early Childhood E-Port Information Systems." This is intended as an evaluation material for the success of community service activities that have been carried out, and how the effectiveness of authentic assessments with e-port assessment information systems for early childhood implemented.

\section{METHOD}

\section{A. Research Design}

The design of the study is interpreted as a scientific way to get data with purpose and usefulness, in this case, the author uses a research design to find out how much the effectiveness of authentic assessment with the E-Port information system of Early Childhood at the PAUD Institute in Malang City.

The approach in this study is a quantitative approach which is a research method used to examine certain populations or samples. This research is an ex-post facto research, which is a research conducted to examine the events that have occurred which then traces back to find out 
the factors that can cause the event. Treatment of ex-post facto research has occurred before the researcher did it. The researcher did not control the treatment.

\section{B. Population and Sample}

The population in this study were PAUD educators in 15 (fifteen) institutions in Klojen sub-district that used 30 early childhood e-port information systems. The sampling technique in this study is to use purposive sampling technique. The sample is determined based on the purpose of the study. Researchers determine the sample by finding information about the population that is in accordance with the needs in the study. In order for this study to run as expected, the authors make a specific criterion for determining early childhood educators included in the population where sampling is taken into account with the consideration of early childhood educators who act as guardians and are tasked with inputting children's development with the e-information systems early childhood port.

\section{Research Instruments}

The instrument used in this study is an instrument for the effectiveness of authentic assessment based on the Indicators of Effectiveness Assessment of Young Children by NAEYC (2003) which is adapted to national standards for authentic K13 PAUD assessment. The variables to be studied related to the effectiveness of the implementation of authentic assessment with e-port information systems for early childhood are as follows. (1) Ethics in the implementation of authentic assessment, namely assessment is a joint responsibility/team and not a single assessment; (2) assessment is carried out consistently with the right and accountable instruments; (3) assessment is carried out according to the stages of child development and objective; (4) valid and reliable assessment criteria; (5) assessment of significant development outcomes from time to time; (6) documentation of processes and tangible results to improve learning implementation practices; (7) results of real work/authentic evidence; (8) documentation of assessments is collected systematically; (9) screening or periodic reports for follow-up; (10) standard assessment / assessment indicators; (11) communication with parents and interested parties; (12) utilization of technology in the implementation of authentic assessments [3].

Authentic assessment is the joint responsibility of both educators and counselors. Educators involve students in choosing activities, the best work that will be input into early childhood e-port information systems. Educators provide assessments related to the process and result consistently with instruments that are in line with the achievements of child development inputted by educators in the rubric menu on early childhood e-port information systems. The rubric input menu is presented by giving the educator the freedom to formulate a more detailed assessment instrument with the stages of child development so that the assessment input is done objectively based on the rubric. The rubric in the early childhood e-port information system is a menu that is manually inputted by educators in relation to valid assessment criteria according to the activities designed by the educator and the achievement competencies to be achieved.

Assessment of the early childhood e-port information system is carried out consistently as a daily, weekly, monthly, and semester assessment as a report at the end of the school year. Child labor results are consistently inputted in the form of voice recordings, videos, scanning of works, and documentation of children's work in digital form. Early childhood e-port information systems provide menu choices for parents to see the processes and results of children's activities while on PAUD online through smartphones and institutional websites. Parents can provide feedback/comments related to child development online and directly through the activities of parent meetings held by PAUD by displaying a children's portfolio showcase.

Authentic assessment has several characteristics, as summarized by Basuki and Hariyanto as follows: (a) involving real experience; (b) carried out during and after the learning process takes place; (c) includes personal assessment; (d) measured skills and performance, not remembering facts; (e) continuous; (f) integrated; (g) can be used as feedback; (h) clearly known criteria for success and failure of students; (i) using various instruments, measurements, and methods that are appropriate to the characteristics and essence of the learning experience; $(\mathrm{j})$ is comprehensive and holistic which covers all aspects of the learning objectives [4]. Authentic assessment has characteristics that emphasize that what is measured is not remembering facts, using various instruments, measurements, and methods that are in accordance with the competency achievement characteristics and are covering all aspects of development.

\section{Data analysis}

Data analysis is an activity after all data from respondents has been collected. Activities in data analysis are grouping data based on variables, presenting data for each variable studied, performing calculations to answer the formulation of the problem, and performing calculations to test the hypothesis that has been proposed. The data analysis used by researchers in this study is associative analysis.

1) Associative analysis. The associative analysis is the analysis used to discuss quantitative data. Assuming that the data is normally distributed and the influence of both linear variables, testing with hypotheses is done using parametric statistics because this technique is in accordance with quantitative data, namely data in the form of numbers. The analysis consists of product moment correlation analysis, the coefficient of determination and significance testing with the t-test.

2) Design of hypothesis testing. The design of hypothesis testing begins with the determination of the null hypothesis (Ho) and the alternative hypothesis (Ha), the determination of statistical tests and testing the hypothesis of determining the level of significance. The design of testing the hypothesis in this study aims to determine whether or not there is influence between the independent variable $(\mathrm{X})$ and the dependent variable $(\mathrm{Y})$. The design of testing hypotheses begins with the determination of the null hypothesis (Ho) and the alternative hypothesis (Ha), Determination of statistical tests, testing hypotheses and determining the level of significance. 


\section{RESULT AND DISCUSSION}

\section{A. The Implementation of Authentic Assessment Using E- Port Information Systems for Early Childhood}

This research is based on the use of early childhood eport information systems in the implementation of authentic assessments in PAUD institutions throughout the city of Malang. Authentic assessment of authentic assessments of early childhood education is a meaningful assessment carried out by educators continually prioritizing processes and outcomes according to the level of achievement of child development. The use of early childhood e-port information systems has been tested for feasibility in previous studies. Early childhood e-port information systems themselves are one of the technology-based assessment innovations that can be used as authentic assessment reports in PAUD institutions [5].

The implementation of authentic assessments using early childhood e-port information systems is concluded to be well received. Educators in carrying out authentic assessments include the process and results of child development achievements recorded in digital form and stored in the form of files that are easily accessed by educators and presented to the child's parents authentically. Basuki \& Hariyanto "due to the main characteristics of portfolio assessment is the emphasis on the evidence of the learning process" [4].

Those is in accordance with the description of Kostelnik et al "organization and use of authentic assessment: Portfolio. Portfolio is a matching assessment with how children learn" [6]. The portfolio is a recommended assessment strategy for the implementation of authentic assessments of early childhood education. The achievement of child development is described according to the rating scale and rubric that can be determined by the educator in accordance with the level of achievement of the expected development.

Educators in carrying out authentic assessments using the Early Childhood E-Port information system in accordance with the principles of assessment in the regulation of the Minister of Education and Culture of the Republic of Indonesia Number 137 of 2014 concerning National Standards for Early Childhood Education Guidelines state that assessment principles are educational, authentic, objective, accountable and transparent that is carried out in an integrated, sustainable and meaningful manner.

Educative is an assessment that encourages children to achieve optimal development outcomes. Authentic is an assessment that is oriented towards continuous learning activities and learning outcomes that reflect the child's ability to carry out learning activities. Objectives are assessments that are based on indicators of progress and are free from the influence of the subjectivity of the appraisers and those assessed is an accountable implementation of assessment in accordance with clear procedures and criteria, and is determined at the beginning of learning. Transparent is an assessment of procedures and assessment results that can be accessed by all stakeholders.

\section{B. The Effectiveness of Authentic Assessment Using E-Port Systems for Early Childhood}

This research aims to find out the effectiveness of authentic assessment using E-Port information systems for early childhood in PAUD institutions throughout Malang. A total of 15 PAUD institutions are spread into 5 sub-districts throughout Malang. Educators who apply early childhood eport information systems are educators who have information technology capabilities.

Based on the results of research that has been carried out which is a follow-up of community service activities will be training of early childhood e-port information systems to representatives of PAUD institutions throughout the city of Malang that the use of early childhood e-port information systems contributes to the effectiveness of the implementation of authentic assessments in PAUD institutions in Malang.

The increased activity of authentic assessments using early childhood e-port information systems demonstrates the effectiveness of conducting authentic assessments with eport early childhood. Bagnato recommends how to carry out authentic assessments in real life as follows: (a) share assessment responsibilities with a team, (b) conduct assessment over time, (c) become the "orchestrator" of authentic assessment across people, context, and occasions, (d) Match the team assessment model to the child, (e) rely on parent judgment and observations, (f) select a common instrument to unify interdisciplinary and interagency teamwork, (g) employ jargon-free materials, (h) use sensitive instruments to gauge child progress, (i) use technology to facilitate authentic assessment and check progress of the program evaluations [7]. Assessment is a shared responsibility and is carried out from time to time consistently. Involve parents in assessment, and use appropriate instruments to measure children's progress and utilize technology to facilitate authentic assessment and as program evaluation [8].

\section{CONCLUSION AND SUGGESTION}

\section{A. Conclusion}

Based on the research findings that have been made related to the implementation of authentic assessments using e-port information systems of early childhood in PAUD institutions throughout the city of Malang, it is concluded that they are well received. Educators in carrying out authentic assessments include the process and results of child development achievements recorded in digital form and stored in the form of files that are easily accessed by educators and presented to the child's parents authentically.

Based on the result of the data analysis of the effectiveness of authentic assessments using early childhood e-port information systems in PAUD institutions throughout Malang, it was concluded that the use of early childhood eport information systems was effective in improving the implementation of authentic assessments in PAUD institutions throughout Malang with a presentation rate of $76,5 \%$ where the higher the use of e-port in early childhood, the implementation of authentic assessment will be more effective, whereas the lower the use of e-port in early childhood, the implementation of authentic assessment will be less effective. 


\section{B. Suggestion}

Suggestion from the results of this study is the use of early childhood e-port information systems in the implementation of authentic assessment can be used throughout PAUD institutions because it is effective in carrying out the authentic assessment of early childhood.

\section{REFERENCES}

[1] Peraturan Menteri Pendidikan dan Kebudayaan Republik Indonesia Nomor 146 Tahun 2014 tentang Kurikulum 2013 Pendidikan Anak Usia Dini, 2014.

[2] Ika. "Penerapan Kurikulum 2013 Makin Matang" diakses melalui http://radarmalang.co.id/penerapan-kurikulum-2013-makin-matang9910.htm pada tanggal 10 Februari 2017, 2015.

[3] National Association for the Education of Young Children (NAEYC) and National Association of Early Childhood Specialists in State Departments of Education (NAECS/SDE), 2003, pp.10-11 file:///E:/NAEYC/naeyc\%20assesment.pdf
[4] I. Basuki \& Hariyanto. Asesmen Pembelajaran, 2014, Bandung: PT. Remaja Rosdakarya.

[5] L. Gonadi. Pengembangan E-Portfolio Capaian Perkembangan Anak Usia Dini. 2015. Surabaya: Unesa (Thesis).

[6] M. J. Kostelnik, A. K. Soderman, A. P. Whiren, \& M. L. Rupiper. Developmentally Appropriate Curriculum: best Practices in Early Childhood Education 4th. New Jersey: Pearson Prentice Hall, 2007.

[7] J. S. Bagnato. Authentic Assessment For Early Childhood Intervention. The Guilford Press. New York. London, 2007.

[8] S. Nurhayati \& A. Rakhman. Studi kompetensi guru paud dalam melakukan asesmen pembelajaran dan perkembangan anak usia dini di kota cimahi. On Indonesian Islam, Education And Science (ICIIES) 2017, 557. 